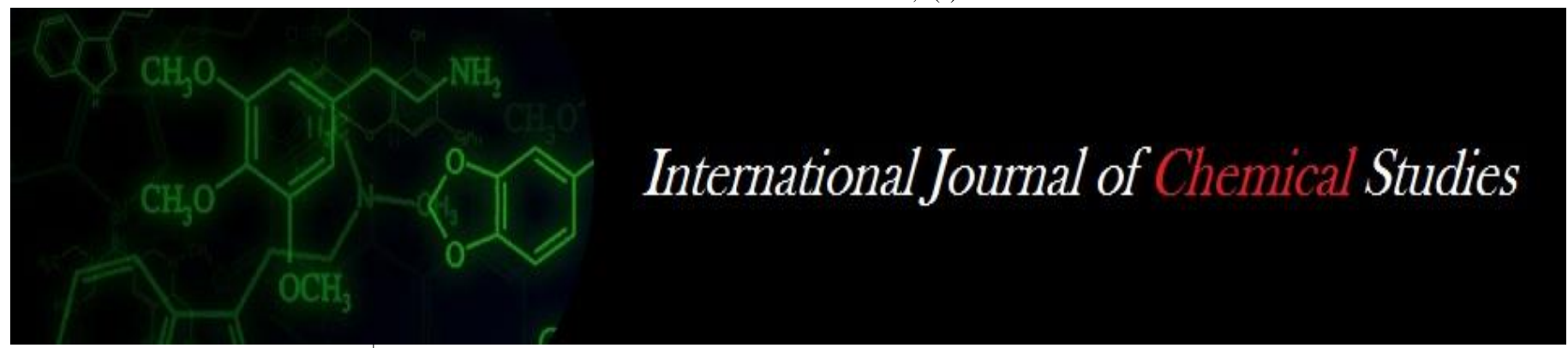

P-ISSN: 2349-8528

E-ISSN: 2321-4902

www.chemijournal.com

IJCS 2020; 8(1): 2789-2790

(C) 2020 IJCS

Received: 28-11-2019

Accepted: 30-12-2019

Sudipta Sahoo

M.Sc. (Ag.), Department of Plant

Pathology, College of

Agriculture, OUAT,

Bhubaneswar, Odisha, India

\section{SK Beura}

Professor and Head, Department

of Plant Pathology, College of

Agriculture, OUAT,

Bhubaneswar, Odisha, India

\section{RP Subudhi}

M.Sc. (Ag.), Department of

Nematology, College of

Agriculture, OUAT,

Bhubaneswar, Odisha, India
Corresponding Author: Sudipta Sahoo

M.Sc. (Ag.), Department of Plant

Pathology, College of

Agriculture, OUAT,

Bhubaneswar, Odisha, India

\section{Chemical management of Helminthosporium vignicola: The incitant of cowpea target leaf spot}

\section{Sudipta Sahoo, SK Beura and RP Subudhi}

DOI: https://doi.org/10.22271/chemi.2020.v8.i1ap.8693

\begin{abstract}
The target leaf spot disease of cowpea incited by Helminthosporium vignicola is a new emerging threat to all the cowpea growers of Odisha. Coastal districts of Odisha are mainly inflicted by this leaf spot disease. An in-vitro experiment was conducted at the Plant Pathology Laboratory of College of Agriculture, OUAT, Bhubaneswar to test the effect of some fungicides on radial growth inhibition of $H$. vignicola. The efficacy of ten fungicides viz. Hexaconazole 5\%EC, Zineb 75\% WP, Hexaconazole 68\% + Zineb 4\%WP, Azoxystrobin 23\% EC, Tebuconazole 250EC, Azoxystrobin 11\%+ Tebuconazole 18.3\%SC, Mancozeb 75\%WP, Azoxystrobin 8.3\%+ Mancozeb 66.7\% WG, Cymoxanil 8\% + Mancozeb $64 \% \mathrm{WP}$ and Difenoconazole 250SC were carried out against $H$. vignicola by poison food technique. All the fungicides notably reduced the growth of fungus included under investigation. Among all the fungicides Azoxystrobin $11 \%+$ Tebuconazole $18.3 \% \mathrm{SC}$ recorded maximum fungal growth inhibition (98.7\%) followed by Tebuconazole 250EC (95.1\%) and Difenoconazole 250 SC (89.0\%).
\end{abstract}

Keywords: Cowpea, Helminthosporium vignicola, fungicides, management

\section{Introduction}

Cowpea is one of the most ancient human food sources and has probably been used as a crop plant since Neolithic times. It is indigenous to Africa from which it was introduced into other tropical and subtropical countries (Cobley and Steele, 1975) ${ }^{[1]}$. It is now grown in many regions of Africa, India, Brazil, U.S.A., the West Indies, Australia, Pakistan and parts of Europe and South America (Rachie and Roberts, 1974). In Odisha, the districts like Cuttack, Nayagarh, Kalahandi, Puri, Jagatsinghpur, Keonjhar, Nabarangpur and Boudh are leading areas where significant cowpea production occurs. In our state, cowpea occupies an area of 0.53 lakh hectares with an annual production of 0.40 lakh tonnes with an average productivity of $748 \mathrm{~kg} / \mathrm{ha}$ (OUAT strategies for pulse production in rice fallows of Odisha, 2016). Unfortunately cowpea is inflicted by an array of diseases, but the target leaf spot disease caused by Helminthosporium vignicola is experienced for the first time during Kharif-2017 in AICRP on Vegetable crops, OUAT, Bhubaneswar and adjoining coastal tracts of Odisha. As the disease is occurring severely in recent years causing considerable loss in yield, not much is known about its management. Hence the current study was undertaken in the laboratory so as to evaluate the efficacy of various fungicides against this pathogen.

\section{Materials and Methods}

Cowpea leaf samples showing leaf spot symptoms were collected from AICRP on Vegetable Crops, OUAT, Bhubaneswar and some coastal districts of Odisha. Leaves with typical symptoms were first washed in tap water and then cut into small bits measuring $2 \mathrm{~mm}$ size. These bits were surface sterilized with 0.1 per cent $\mathrm{HgCl}_{2}$ solution for two minutes followed by three changes of sterilized distilled water. These bits were placed on potato dextrose agar under aseptic condition. Inoculated plates were incubated at $27{ }^{\circ} \mathrm{C}$ for seven days. After seven days of incubation, fungal colonies completely covered the plates and become black in colour indicating the production of spores. The pure culture so obtained was maintained on PDA slants at $4+1{ }^{0} \mathrm{C}$.

The comparative study of different fungicides on the growth of the fungus under in-vitro condition was assessed by poison food technique. 


\section{Poison food technique}

The fungicides like Hexaconazole 5\%EC, Zineb 75\% WP, Hexaconazole 68\% + Zineb 4\%WP, Azoxystrobin 23\% EC, Tebuconazole 250EC, Azoxystrobin11\%+Tebuconazole 18.3\%SC, Mancozeb, Azoxystrobin8.3\%+Mancozeb $66.7 \%$ WG, Cymoxanil 8\% + Mancozeb 64\%WP and Difenconazole 250SC were used for in-vitro assay. The prepared PDA medium was first sterilized in the autoclave at $15 \mathrm{psi}$ for $15-20$ minutes. The required concentrations of chemicals were prepared and incorporated into sterilized, cooled potato dextrose agar medium. Twenty $\mathrm{ml}$ of medium was poured into $90 \mathrm{~mm}$ sterilized Petriplates and all plates were inoculated with actively growing $9 \mathrm{~mm}$ mycelial disc of test fungus. The petriplate containing PDA without any fungicide served as control. Three replications were maintained for each treatment. These plates were incubated at $25 \pm 1{ }^{\circ} \mathrm{C}$ for fourteen days and then colony diameter was recorded when the fungus attended maximum growth in control petriplates. Per cent inhibition of mycelial growth over control was calculated by using the formulae of Vincent (1947) ${ }^{[4]}$.

$\mathrm{I}=\frac{(C-T)}{C} \times 100$

Where,

$\mathrm{I}=$ Per cent inhibition of mycelium

$\mathrm{C}=$ Growth of mycelium in control

$\mathrm{T}=$ Growth of mycelium in treatment
The data obtained on per cent growth inhibition of test fungus were statistically analysed and corresponding angular transformed values were stated.

\section{Results and Discussion}

It is clearly inferred from the above table 1 that most of the fungicides were efficient in restricting the growth of $H$. vignicola as compared to control. Among all the fungicides tested, Azoxystrobin $11 \%+$ Tebuconazole $18.3 \%$ SC exhibited maximum fungal growth inhibition $(98.7 \%)$ followed by Tebuconazole 250EC (95.1\%). The next best inhibition was recorded by Difenoconazole $250 \mathrm{SC}$ followed by Hexaconazole $68 \%$ + Zineb $4 \%$ WP which opined more than 85 per cent inhibition. The minimum growth inhibition was recorded by Zineb $75 \%$ WP $(62.9 \%)$. All the fungicides inhibited the mycelial growth over control ranging from 62.9 to 98.7 per cent.

Harlapur et al. (2007) ${ }^{[3]}$ reported that maximum mean percent inhibition ofmycelial growth of Excerohilum turcicum was obtained with Mancozeb @ $0.25 \%$ while working on turcicum leaf blight disease in maize which supports the present findings.

Since target leaf spot disease is a new report from cowpea in Odisha condition and to manage the disease, some of the promising chemicals such as Azoxystrobin $11 \%+$ Tebuconazole $18.3 \%$ SC, Tebuconazole 250EC and Difenoconazole $250 \mathrm{SC}$ have proved efficacious against $H$. vignicola. Therefore, the chemicals may be tested under field condition in Multi locational trials (MLTs) to draw the conclusion for greater interest of farming community.

Table 1: Efficacy of different fungicides on mycelial growth of Helminthosporium vignicola

\begin{tabular}{|c|c|c|c|c|}
\hline SI. No & Chemical name & Concentration (\%) & Mean Mycelial Growth (mm) & $*$ Per cent growth inhibition \\
\hline 1 & Hexaconazole 5\% EC & 0.05 & 20.50 & $69.7(56.60)^{* *}$ \\
\hline 2 & Zineb 75\% WP & 0.25 & 25.0 & $62.9(52.48)$ \\
\hline 3 & Hexaconazole 68\% + Zineb 4\% WP & 0.20 & 8.38 & $87.5(69.30)$ \\
\hline 4 & Azoxystrobin 23\% EC & 0.10 & 22.31 & $66.9(54.88)$ \\
\hline 5 & Tebuconazole 250EC & 0.10 & 3.26 & $95.1(77.21)$ \\
\hline 6 & Azoxystrobin11\%+Tebuconazole18.3\%SC & 0.10 & 0.83 & $98.7(83.45)$ \\
\hline 7 & Mancozeb 75\% WP & 0.25 & 24.83 & $63.2(52.65)$ \\
\hline 8 & Azoxystrobin8.3\%+mancozeb 66.7\% WG & 0.15 & 12.73 & $81.1(64.23)$ \\
\hline 9 & Cymoxanil 8\% + mancozeb 64\%WP & 0.15 & 19.4 & $71.2(57.54)$ \\
\hline 10 & Difenoconazole 250 SC & 0.05 & 7.4 & $89.0(70.63)$ \\
\hline 11 & Control & - & 67.5 & - \\
\hline & SE(m) \pm & 0.091 & & \\
\hline & CD $(0.05)$ & 0.268 & & \\
\hline
\end{tabular}
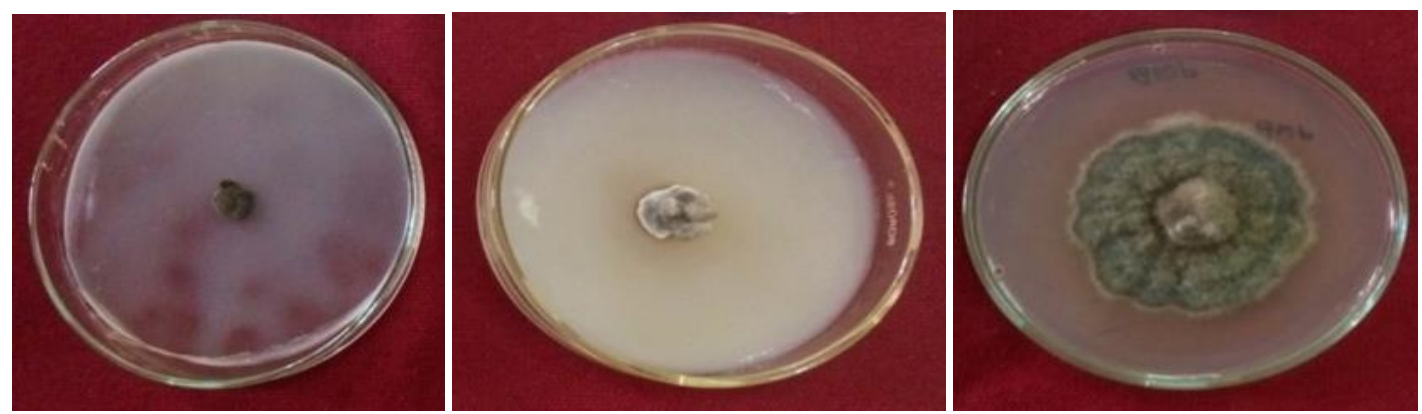

Fig 1: Maximum inhibition of test pathogen by fungicides. A. Azoxystrobin 11\% + Tebuconazole 18.3\% SC, B. Tebuconazole $250 \mathrm{EC}$, C. Control

\section{References}

1. Cobley LS, Steele WM. An Introduction to the Botany of Tropical Crops (London: Longman), 1975, 371.

2. Rachie KG, Roberts LM. Grain legumes of the low land tropics, Advances in Agronomy. 1974; 26:1-32.

3. Harlapur SI, Kulkarni MS, Wali MC, Kulkarni S. Evaluation of plant extracts, bio-agents and fungicides against Exserohilum turcicum (Pass) Leonard and Suggs. Causing turcicum leaf blight of maize, Karnataka Journal of Agricultural Science. 2007; 20(3):541-544.

4. Vincent JM. Distribution of fungal hyphae in per cent of certain inhibitors, Nature. 1947; 96:596. 